\title{
The Trans-Anatolian Pipeline (TANAP) as a unique project in the Eurasian gas network: A comparative analysis
}

\author{
Volkan Özdemir ${ }^{\text {a, }}{ }^{*}$, H. Buğra Yavuz ${ }^{\text {b }}$, Emine Tokgöz ${ }^{c}$ \\ ${ }^{a}$ EPPEN (Institute for Energy Markets and Policies), Ankara, Turkey \\ b TPIC (Turkish Petroleum International Company), Ankara, Turkey \\ ${ }^{\mathrm{c}}$ Competition Authority of Turkey, Ankara, Turkey
}

\section{A R T I C L E I N F O}

\section{Article history:}

Available online 27 June 2015

\section{Keywords:}

Natural gas

Liberalization

Competition

TANAP

Third-party access

\begin{abstract}
A B S T R A C T
Trans-Anatolian Gas Pipeline (TANAP) as a part of the Southern Gas Corridor has significant implications for the transit security of the European Union and the domestic gas market of Turkey. Among those countries in Eurasia, only Turkey's process of liberalization is a success story, albeit an incomplete one. Surrounded by liberal markets to the West and monopolistic markets to the East, Turkey partially possesses a competitive gas market. TANAP, a unique project among the international pipelines in Eurasia, strengthens Turkey's peculiar position by de facto ending the monopoly of the incumbent BOTAŞ over gas transmission and thus contributes to the liberalization of the domestic market.
\end{abstract}

(c) 2015 Elsevier Ltd. All rights reserved.

\section{Introduction}

For the last three decades, the energy industry has been witnessing that a market-oriented paradigm, with its promise of efficiency and sustainability, has superseded the traditional regulation paradigm (Cameron, 2007). The natural gas industry, traditionally closed to competition, has been subjected to liberalization through the easing of entry barriers into the commercial segments of the supply chain. In this quest to dismantle entry barriers for the new suppliers through vertical disintegration, many jurisdictions promoted the norm of non-discriminatory access of the third parties to the network (transmission and distribution networks possessing natural monopoly characteristics) (Haase, 2008; Viscusi et al., 2005). The liberal, transparent and competitive structure of the North American gas market has been taken as a model throughout the world. The European Union (EU) has also been struggling to create a liberal and integrated European gas market, the last step of which is the 3rd Energy Package. The most significant characteristic of the European gas market is its high level of dependency on pipeline imports from Russia, the Caspian region and the North Africa. In this sense, changes and developments in the regulatory framework of the gas industry in Europe have profound effects

\footnotetext{
* Corresponding author.

E-mail addresses: ozdemirvolkan@gmail.com (V. Özdemir), hby908gs@gmail. com (H.B. Yavuz), etokgoz@rekabet.gov.tr (E. Tokgöz).
}

beyond its borders and especially in Eurasia. Among those countries in Eurasia (Turkey, the Russian Federation, the Caspian region and Central Asian republics), only in Turkey has liberalization been undertaken with necessary legal and institutional arrangements starting from 2001. ${ }^{1}$ The main policy target of Turkey, surrounded by liberal markets to the West and monopolistic markets to the East, is to harmonize its energy legislation with the acquis communitaire. Since creating gas-to-gas competition and the dilution of BOTAŞ's dominance are mandatory to achieve liquidity, any new investment needs to be considered in terms of its virtues and vices in terms of competition as well as supply security.

Gas transmission constitutes a critical component of the gas supply chain, which frequently experiences transit and access issues, and the challenging national efforts of liberalization. Since transit countries are usually gas consumers themselves, harmonizing the existing and new transit and the supply contracts in the evolving market infrastructure has become a very important issue for the regulators in the process of liberalization. The Trans Anatolian Pipeline (TANAP) is mainly discussed in terms of its contribution to supply security within the concept of the European Southern Gas Corridor concept, in this paper its impact on competition in the Turkish domestic gas market is analyzed and it is

\footnotetext{
${ }^{1}$ Sector-specific market laws and establishment of an independent NRA (national regulatory authority) were the first important steps toward a liberalized energy industry regime.
} 
argued that since it has the ability to create a competitive pressure on BOTAŞ (Turkish pipeline corporation, the dominant incumbent), TANAP is notable as a unique project compared to other international gas pipelines existing in the region. When TANAP becomes operational, Turkey will become the only non-EU member country in Eurasia where the existing monopoly over transmission will be ended. TANAP, which is similar to the Eurasian pipelines in terms of its contribution to energy (supply) security and potential to enhance competition, departs from its counterparts in terms of its physical properties (simultaneously international and domestic) and enjoying a full exemption despite its potential to serve as an accelerator of national efforts for gas market liberalization.

TANAP can thus be described as a new generation pipeline that brings more equity in terms of serving the interests of the countries involved in the supply chain. Not only diluting the supply and transmission dominance of Gazprom, TANAP also exposes the economic (competition and regulatory policies) and political deficiencies of the existing Eurasian pipelines whose international and cross-border character has blocked the involved countries' interest-maximization.

In this respect, section two of this article will explicate the novelty of TANAP in comparison with its counterparts in Eurasia to see how TANAP does not fit into any category of the extant pipelines in the region. Since the realization of TANAP has repercussions for a broad range of markets (the Caspian, Turkish, European), the third section will clarify TANAP's role in the Southern Gas Corridor. The fourth section will present the regulatory and competition policy framework to understand the institutional regime surrounding TANAP. The conclusion will describe TANAP's potential to provide both supply security and enhance competition signifying the importance of institutional design and the inferiority of traditional pipeline models in Eurasia.

\section{International projects and cross-border pipelines in Eurasia}

A robust gas trade can only take place with access to a wellconnected and well-managed transmission network. Issues such as risky investment, access and dependence on foreign resources have elevated energy security and international gas trade to the top of the agenda. Long-term Take or Pay (ToP) contracts have made international gas trade possible by splitting price and volume risks between the seller and the buyer and state regulations have been enacted to guarantee this structure (Mitrova, 2009). It is not surprising that one third of all the gas consumed globally is internationally traded and almost two thirds of this amount is transported through international gas pipelines (BP Statistical Review, 2013). With growing interdependence, suppliers and consumers alike have become even more concerned about gas transit security. Advanced technology and the growth of demand instigated the development of international markets with large-scale crossborder gas pipelines, as in the numerous examples that exist in Eurasia.

Since Eurasian countries, excluding Turkey and Iran, are remnants of the Soviet Union, their gas market structures are similar in the sense that following the collapse, each newly independent state established its own state-owned, vertically integrated gas monopoly, awarding it the sole control over the transmission network. This is also the case in Iran and, until recently, in Turkey. ${ }^{2}$ One

\footnotetext{
${ }^{2}$ In Russia, the Unified Gas Supply System is owned by Gazprom, in Azerbaijan by SOCAR and in Ukraine by Neftgaz Ukrainy. In some cases, those transmission networks have been bought by the incumbents of neighboring countries as in the case of Beltransgaz by Gazprom and the Georgian gas network by SOCAR.
}

common feature in each country is that gas transmission is granted a statutory monopoly and there is lack of competitive pressure to the incumbent in gas transmission considering the sunken capital. Moreover, if the incumbent is also active in the supply business and there is no open access policy in place, the lack of liquidity in wholesale markets becomes perpetual.

In Eurasia, cross-border pipelines, regulated by long-term intergovernmental agreements (IGAs), can be seen as a part of international projects. TANAP, the most recent pipeline in Eurasia is unique. Although TANAP is an international project it differs in that it is not a cross-border operation. Rather it can be accepted as a completely national pipeline thus having important repercussions for the Turkish domestic market structuring. Table 1 shows that, all pipelines in the region are either part of a larger project or purely cross-border however, TANAP recognizes the sovereignty of the Turkish government at the same times as being part of a larger project. In that sense, TANAP brings a new dimension to Eurasian energy security in which cross-border pipelines have been representatives of the sole characteristics for pattern of gas trade in the continent for decades.

\subsection{The pipelines in Eurasia: the traditional structuring of export pipelines}

The pipelines in Eurasia can be categorized in three major subgroups:

a) Russia-Europe international gas export pipelines, which all reflect traditional business model of ToP, oil-indexed and with a long-term relationship. Ukraine and Belarus are main transit routes. There are also off-shore pipelines which are projected to cover the increase in demand from Europe and all these pipelines target final consumer i.e. EU markets with very limited effects on domestic gas markets in the Former Soviet Union.

b) Cross-border gas-export pipelines of Central Asia, which mainly aim to transport Turkmen gas since the post-Soviet era provided a leeway for sovereign exportation from the resource-rich former Soviet Republics. Kazakhstan and Uzbekistan stand, as the main corridors while China and Iran are the main benefactors.

c) Other non-Russian international gas export pipelines, which mainly link Iran, Azerbaijan and Turkey to extend further into Europe. Although TANAP can be placed in this sub-group, as the comparison Section 3 will demonstrate, TANAP is beyond being subservient to the source or destination jurisdictions.

\subsection{Common traits of international and cross-border pipelines vs. TANAP}

All the established or proposed pipelines with a background in either the Soviet or Post-Soviet era, are cross-border and international pipelines that transfer the gas commodity from Russia and the former Soviet Republics to Europe. The important commonality of all these aforementioned large-capacity projects is the long-term investment that is fostered on the soil of the former Soviet Union. No former Soviet Republic in the Central Asia has access to the demand without these cross-border and international pipelines.

Since international and thus cross-border infrastructure is involved in gas trade, diplomacy has been an indispensable part of export of Eurasian energy to the EU. Russia's dominance over Europe in gas imports has been consolidated through export of the Russian and Central Asian oil and gas sources via the Soviet Era pipelines as well as newly established pipelines such as Nord Stream. However, countries in Eurasia, either as source or transit countries, have been trying to break this domination by proposing 
Table 1

Main cross-border gas pipelines in Eurasia.

\begin{tabular}{|c|c|c|c|c|c|}
\hline Pipeline & Controlling body & Time element & Entry & Exit and off-take & Capacity (bcm) \\
\hline Brotherhood\&Trans-Balkan & $\begin{array}{l}\text { Gazprom } \\
\text { Naftogaz }\end{array}$ & Soviet period & Russia & $\begin{array}{l}\text { Ukraine, } \\
\text { The Balkans }\end{array}$ & 100 \\
\hline Trans-Siberian & $\begin{array}{l}\text { Gazprom } \\
\text { Naftogaz }\end{array}$ & Soviet period & Russia & $\begin{array}{l}\text { Europe } \\
\text { Ukraine }\end{array}$ & 32 \\
\hline Soyuz & $\begin{array}{l}\text { Gazprom } \\
\text { Naftogaz }\end{array}$ & Soviet period & $\begin{array}{l}\text { Central Asia } \\
\text { Russia }\end{array}$ & $\begin{array}{l}\text { Northern Europe } \\
\text { Ukraine }\end{array}$ & 32 \\
\hline Northern Lights & $\begin{array}{l}\text { Gazprom } \\
\text { Beltransgaz }\end{array}$ & Soviet period & Russia & $\begin{array}{l}\text { Europe } \\
\text { Belarus }\end{array}$ & 51 \\
\hline Yamal-Europe & $\begin{array}{l}\text { Gazprom } \\
\text { Beltransgaz } \\
\text { EuroPolGaz }\end{array}$ & Operational since 1992 & Russia & $\begin{array}{l}\text { Germany } \\
\text { Poland } \\
\text { Belarus }\end{array}$ & 32 \\
\hline Blue Stream & $\begin{array}{l}\text { Gazprom } \\
\text { ENI }\end{array}$ & Signed in 1997 & Russia & Turkey & \\
\hline Nord Stream & $\begin{array}{l}\text { Gazprom } \\
\text { E.on Ruhrgas } \\
\text { Wintershall } \\
\text { Gasunie } \\
\text { GDF Suez }\end{array}$ & 2011 & Russia & Europe & 55 \\
\hline Central Asia Center & $\begin{array}{l}\text { Turkmengas } \\
\text { Uzbekneftegaz } \\
\text { Kazmunaygaz } \\
\text { Gazprom }\end{array}$ & Soviet period & Turkmenistan & Russia & 90 \\
\hline Trans-Asia & $\begin{array}{l}\text { Turkmengas } \\
\text { Uzbekneftegaz } \\
\text { Kazmunaygaz } \\
\text { CNPC }\end{array}$ & Contemporary & Turkmenistan & China & 55 \\
\hline Turkmenistan-Iran & $\begin{array}{l}\text { Turkmengas } \\
\text { NIGC }\end{array}$ & Commissioned in 1997 & Turkmenistan & Iran & 18 \\
\hline Iran-Turkey & $\begin{array}{l}\text { NIGC } \\
\text { BOTAS }\end{array}$ & Operational since 1999 & Iran & Turkey & 10 \\
\hline Azerbaijan-Russia & $\begin{array}{l}\text { Gazprom } \\
\text { SOCAR }\end{array}$ & 2010 & Azerbaijan & Russia & 5 \\
\hline South Caucasus & Shah Deniz Consortium & 2006 & Azerbaijan & $\begin{array}{l}\text { Turkey } \\
\text { Georgia }\end{array}$ & 8,8 \\
\hline Turkey-Greece & $\begin{array}{l}\text { BOTAS } \\
\text { DESFA }\end{array}$ & 2007 & $\begin{array}{l}\text { Azerbaijan } \\
\text { Turkey }\end{array}$ & Greece & 7 \\
\hline
\end{tabular}

Source: Derived from different sources by the authors.

new oil and gas pipelines that bypass Russian territory.

The Baku-Tbilisi-Ceyhan Oil Pipeline and the Baku-TbilisiErzurum Gas Pipeline (South Caucasus Pipeline), built after the dissolution of the Soviet Union, are important examples of pipelines creating an alternative to the Russian-controlled export routes. TANAP is the most recent example of such an alternative route.

TANAP has served as an enabler for the realization of the Southern Gas Corridor project (Koranyi, 2014). The State Oil Company of Azerbaijan (SOCAR) will control the gas exports to Europe via Turkey. Since Turkey is not an EU member, the project is not bound by the EU third party access (TPA) regime. In 2020, Azerbaijan plans to ship additional quantities of gas to Europe beyond the initial $10 \mathrm{bcm}$ from the Shah Deniz II field, and include prospective fields such as Absheron, Umid and ACG Deep (Koranyi, 2014). From a long-term perspective, SOCAR will be the sole decision-maker for TPA demands regarding a large volume of gas.

With its initial designed capacity of $16 \mathrm{bcm}$, TANAP will carry gas to another pipeline project Trans Adriatic Pipeline (TAP) run by Statoil, E. On Ruhrgas and EGL. Once TANAP is operational, Azerbaijan will be an important player in the upstream which has been dominated by the interests of the US, Russia and the EU solely (Nanay and Stegen, 2012). While the EU and the United States of America (US) have perceived the project as auspicious for the energy security of the region. TANAP's competition-enhancing role has alarmed the Russian counterparts.

Russian dominance over the Eurasian resources and transmission has been diluted by new generation sui generis projects such as TANAP. The robustness of the new projects is no longer evaluated through an over-weighing of resource-richness or political prowess, as was the case with the aforementioned international and cross-border pipelines. This is the main reason behind the encouragement from the US and EU for bypassing Russia, as well as the Eurasian countries whose interests have been traditionally underestimated (Nanay and Stegen, 2012).

TANAP's uniqueness comes from its promotion of competition both in economic and political terms. Economically, TANAP increases the amount of supply, brings an additional supplier through an alternative route which is controlled not by one nation or state, but by several nation-states. In Turkey, the pipeline is planned to start on the eastern border and ends at the western border with Greece. The TANAP Company will take the responsibility to construct the Turkish portion of the pipeline. In addition to this section, an overall amount of $163 \mathrm{bcm}$ will be carried through the Southern Gas Corridor (Bilgin, 2011). Although TANAP is an international gas transit project but it is evaluated as an internal gas pipeline in Turkey, with $6 \mathrm{bcm}$ of the initial capacity being used in the Turkish domestic market.

\section{Southern gas corridor and TANAP - a unique project in Eurasia}

High level of import dependence and the Russia-Ukraine gas crises led decision makers in Europe take steps diversify the number of resource countries and delivery routes. The European Commission recognized the construction of the Southern Gas Corridor as an energy security priority of the EU, given the increasing level of imports and a forecasted production fall to 163 
bcm (Bilgin, 2011). Head of the EU Commission, Jose Manuel Barroso, summarized this as the EU having committed itself to "develop the Union's energy relations with producer and transit countries with a view to securing stability of supply and diversifying its energy resources" (An EU, 2014).

The initiative of the Corridor was first proposed in the Commission's Communication "Second Strategic Energy Review-An EU Energy Security and Solidarity Action Plan (COM/2008/781)" where six infrastructure actions were proposed to be accepted as community priorities, one of which was: "A southern gas corridor must be developed for the supply of gas from Caspian and Middle Eastern sources which could potentially supply a significant part of the EU's future needs. This is one of the EU's highest energy security priorities" (COM/2008/781). This priority was reiterated in the European Energy Security Strategy 2014, where the expansion of the Corridor is labeled as a "key action" (European Commission, 2014).

Turkey is a key factor in the fulfillment of the development and expansion of the project. This is in keeping with Turkey's aspirations to become an important energy player with its geographical advantage in terms of Eastern producers and the Western consumers and also to become the fourth largest gas artery in Europe after Russia, Algeria and Norway. Therefore, Turkey's energy strategy seems to comply with the European Southern Gas Corridor strategy. With Baku-Tblisi-Ceyhan oil (BTC), SCP and Turkey-Greece Pipeline are now operational; Turkey can claim to have taken an important step towards achieving its aspirations. Turkey is not only a transit country for the transportation of the Caspian supplies but also an emerging natural gas market. Turkey's liquid, transparent and competitive gas market, in the mid-/long-term, has the ability to absorb significant gas volumes available for export from the Caspian as well as other reserves, further enhancing energy security in the region.

In the immediate neighborhood of Europe, the Caspian oil and gas resources are seen as new source of energy to be tapped and mitigate the energy vulnerability of the EU. The Caspian countries have also been seeking market access to Asia and Europe for their reserves through participating in various pipeline projects. These projects are not promoted solely for the prospective income but also to reduce the transport monopoly of Gazprom. Within this framework, a joint declaration on the establishment of the Southern Gas Corridor was signed between Azerbaijan and the EU in 2011, which serves to cover the energy strategies of both parties.

The Turkish part of the Corridor, TANAP, came into being through the Memorandum of Understanding signed between Azerbaijan and Turkey in December 2011. TANAP, led by SOCAR, plans to initially transport gas from the Shah Deniz II field in Azerbaijan with the future prospects of expansion to exploit reserves in the Eastern Mediterranean, Northern Iraq, Turkmenistan and Iran, mainly after 2020. TANAP will be connected to the expanded Southern Caucasus Pipeline Expansion (SCPX) on the Turkish-Georgian border, which will extend across Turkish territory and terminate on the Turkish-Greek border. In fact, before TANAP was initiated, BP proposed the alternative option of using BOTAŞ's existing transport system rather than a standalone line to avoid additional construction and transaction costs (Rzayeva, 2014). The idea was that additional investments for the expansion and improvement of BOTAŞ's transport system would be undertaken to avoid a bottleneck however, the parties opted for more costly TANAP project.

The IGA for the realization of TANAP was signed in Istanbul on 26 June 2012 . The agreement provided a general framework for gas transportation and pricing. The Host Governmental Agreement (HGA) between the Project Company and the Turkish Government followed the IGA. The total cost of the project is estimated to be $\$ 12$ billion and it is planned to be operational in 2018 with an initial capacity of $16 \mathrm{bcm}$ (Rzayeva, 2014). Of these $16 \mathrm{bcm}, 6 \mathrm{bcm}$ will be used in the Turkish domestic market, entering Turkey at the Eskişehir exit point and the remaining $10 \mathrm{bcm}$ will be transported to Europe. TANAP thus completes the missing section of the Southern Gas Corridor and paves the way for the realization of more largescale projects in the region. From the perspective of Turkey's energy security and liberalization policies, TANAP should be examined in terms of its contribution to Turkey's ambition to become a gas hub with a liquid and transparent wholesale market, not solely an energy corridor.

As stated above, TANAP is a unique project and its realization will have profound effects on the Turkish domestic gas market as well as the interrelated markets. SOCAR will operate the project and the 3rd Energy Package will not bind it since Turkey is not a member of the EU or the Energy Community (Koranyi, 2014). The shareholders of the project company and their shares are: SOCAR $58 \%$, BOTAS $30 \%$ and BP $12 \%$. BOTAŞ's shares were raised to $30 \%$ in accordance with the agreement signed in May 2014 in Istanbul, amending the prior HGA (Petroturk, 2014). The construction of the pipeline is planned to begin in 2015 and be completed in 2018. The initial planned capacity is $16 \mathrm{bcm}$ and a gradual expansion to 23 bcm by 2023 and a predicted 31 bcm by 2026 (Rzayeva, 2014). In 2013, the final investment decision was taken to transport gas from the Shah Deniz II field, and the Trans Adriatic Pipeline (TAP) was selected as the interconnector with TANAP to carry $10 \mathrm{bcm}$ gas to the Southern Europe (Koranyi, 2014).

\section{The EU regulatory framework for gas-to-gas competition and gas market liberalization in Turkey}

The interdependence of the network and commercial elements of the gas industry requires fair and transparent transportation services for the new entrants and thus creating increasing liquidity through TPA. Within the EU regulatory framework the 2007, Sector Inquiry undertaken by the European Commission was a milestone for the establishment of a robust TPA regime. In the Sector Inquiry, the Commission found that due to an underdeveloped access regime with necessary anti-hoarding mechanisms for the crossborder and transit pipelines, new entrants failed to secure primary transit capacity. Transit contracts in the EU were found to be valid until 2022, which was alarming since new entrants would not have the opportunity to access transit contracts. The problem was revealed to be more acute if the entrant(s) had to access more than one pipeline. If, however, the transmission system operator had been forced to implement effective congestion management and also undertake the necessary investment to 'maximize the commercially available capacity', then gas-to-gas competition as desired could have been developed. ${ }^{3}$

Naturally, such an access regime is not an absolute policy since a new infrastructure investment for enhancing supply security and dynamic competition also has to be promoted. Exemptions for new pipelines, liquefied natural gas (LNG) and storage facilities on a case-by-case basis are necessary to diversify of sources and routes, increase gas-to-gas competition, allow for ex novo market entry and develop better services for end customers. Thus, the main institutional task for the regulators and policy makers becomes establishing and implementing the access-exemption balance. In terms

\footnotetext{
${ }^{3}$ Anti-hoarding mechanisms are crucial to overcome contractual and physical congestion. The Sector Inquiry also found that the fragmentation of markets with numerous balancing zones and different pipeline systems made 'access conditions opaque' and entry more difficult. When the capacity is allocated on the secondary market, only $5 \%$ could be allocated to a new entrant (other than the national or other member's incumbent). DG Competition Report on Energy Sector Inquiry, 10.1.2007, Brussels, para. 201-3, 213-5, 220, 675-7, 904-7.
} 
of gas market liberalization and competitiveness, the institutional framework needs to attain the right balance between access and exemptions, meaning achieving the right balance between dilution of the market power of the incumbent at the expense of new entrants and new investment with high levels of risk required for secure, diverse and competitive gas supply. Cognizant of the vitality of a balanced access-exemption regime, both second and third Gas Directives (2003/55/EC and 2009/73/EC) contained articles on exemption which once granted, exempts the relevant parties ex ante from ex post regulations. Article 36 of the 2009 Gas Directive presents the following conditions that must be fulfilled cumulatively for an exemption from articles 9, 32, 33 and 34, and 41(6), (8) and (10) to be granted ${ }^{4}$

\section{The investment must enhance competition in gas supply and} enhance security of supply

2. The level of risk attached to the investment must be such that the investment would not take place unless an exemption was granted;

3. The infrastructure must be owned by a natural or legal person which is separate at least in terms of its legal form from the system operators in whose systems that infrastructure will be built;

4. Charges must be levied on users of that infrastructure;

5. The exemption must not be detrimental to competition or the effective functioning of the internal market in natural gas, or the efficient functioning of the regulated system to which the infrastructure is connected.

The Commission also issued the Working Paper on New Infrastructure Exemptions, ${ }^{5}$ which provides guidance and information on transparency about the procedures for assessing exemption applications. Thus, the substance of exemption legislation can be understood from the Working Paper. The first and foremost principle in the application of exemption is to provide a balance between incentivizing the new infrastructure investment necessary to meet reasonable demand and the competitive markets necessary to maximize consumer welfare. This balance is mainly achieved through case-by-case analyses of applications which most often result in partial exemption rather than full exemption. Partial exemptions are common in decisional practice (Talus, 2013) and they either limit the percentage of infrastructure capacity, duration of the exemption and tariff setting or the direction of the flows. The Commission implements a caveat and emphasizes that congestion management and anti-hoarding procedures of the Gas Directive are to be fully implemented regardless of the exemption being fully or partially granted.

Analyzing the decisional practice of the Commission reveals that it has been cautious in providing access-exemption balance by i) employing essential facilities doctrine and article 102 of the TFEU to dilute the incumbents' market foreclosure ii) exempting new infrastructure mostly partially rather than fully and with capacity caps and expansion commitments if the dominant incumbent is the requesting party. Given below is the TAP Exemption decision as an

\footnotetext{
${ }^{4}$ Article 9 regulates transmission unbundling, Article 32 regulates TPA, Article 33 regulates access to storage facilities and Article 34 regulates access to upstream pipelines. Article 41 regulates the jurisdiction and duties of the regulatory authorities. The corresponding article number 36 of the Third Directive is number 22 in the 2003 Directive. When cross-border pipelines are the subject matter cooperation of relevant national authorities is sought.

5 This is the "Commission staff working document on Article 22 of the Directive 2003/55/EC concerning common rules for the internal market in natural gas and Article 7 of Regulation (EC) No 1228/2003 on conditions for access to the network for cross-border exchanges in electricity: New Infrastructure Exemptions" SEC(2009)642 final, 6.5.2009, Brussels. Separate Commission Staff Working Documents have also been published on tariffs for access, preferential access and unbundling individually.
}

important precedent to understand the competition-supply security arguments of the Commission (Merlino and Faella, 2013).

\subsection{Making international pipeline projects feasible: $T A P^{6}$ exemption (2013)}

In 2013, TAP was partially exempted from the relevant regulation by the national regulatory authorities and the Commission. ${ }^{7}$ This was achieved by assessing the project through market tests, evaluating the position of the TAP shareholders and their presence in the national markets, determining the contribution to the supply security and the requirements related to competition, riskiness and functional unbundling. The Commission found that the project fulfilled the security of supply and competition enhancement criteria but imposed conditions as "proper remedies avoiding ... a market position in which they [the shareholders of TAP] are no longer exposed to effective competitive pressure." ${ }^{8}$ In its competitive assessment, the authorities tested both the incentive and the ability to foreclose the market from actual and potential competitors by the incumbents and/or TAP shareholders. As a result, capacity caps for dominant undertakings were ordered and exemption was limited to the initial capacity. Furthermore, to increase liquidity, the Commission stipulated the construction of new exit points and gas/capacity release programs where necessary. A tariff code, a network code and functional and informational unbundling were also required from the relevant parties.

Specifically, TAP's initial capacity $(10 \mathrm{bcm})$ is exempted with certain limitations of dominant undertakings for 25 years from the operation start date whereas expansion capacity $(10 \mathrm{bcm})$ is to be allocated to the market participants through booking procedures described in the Decision in a non-discriminatory and transparent manner. Obligatory additional entry and exit points in Greece will be constructed and functional unbundling of TAP will be fulfilled with certification to be acquired from each country's relevant authority.

The Commission favors an exemption regime, which both promotes new investment and increases competition thanks to conditions and qualifications embedded in the decisional practice. The Commission has adopted the vision of achieving dynamic competition rather than embracing a static perspective and risking the balance between supply security and competition. The main evidence of TPA being the norm while exemption is an exception is based on compromising the power of promoting liquidity through limiting dominant incumbents' grip of market share from new projects.

\subsection{Gas market liberalization in Turkey and TANAP's role in promoting competition}

The competitiveness of wholesale gas market depends on liquidity and an effective TPA guaranteeing fair, nondiscriminatory, transparent access with necessary congestion

\footnotetext{
${ }^{6}$ TAP is an $867 \mathrm{~km}$ pipeline with an initial capacity of $10 \mathrm{bcm}$. Capacity could be increased up to $20 \mathrm{bcm}$ in the future. The project partners are BP(England), SOCAR(Azerbaijan), Statoil(Norway), Fluxys(belgium), Total (France), E.On (Germany) and Axpo (Switzerland). TAP is expected to be operational in 2018.

7 Each regulator in Italy, Greece and Albania individually analyzed the project and the three authorities presented a Joint Opinion to the Commission, after which the Commission reached the final decision. This decision only concerns TAP, the Commission reiterates several times that the TAP operation is tied to the transportation chain of SCP and TANAP. The Commission Decision of 16.5.2013 on the exemption of the Trans Adriatic Pipeline from the Requirements on third party access (TPA), tariff regulation and ownership unbundling was laid down in Articles 9, 32, 41(6), 41(8) and 41(10) of Directive 2009/73/EC.

8 TAP decision, para. 112 .
} 
management and anti-hoarding mechanisms in place. The TAP decision demonstrates that a healthy exemption regime should be able to address competition concerns such as foreclosure, level playing field, and flexibility for the players and the distorted incentives of the dominant incumbent. Therefore, TANAP should be examined and progress in accordance with the goal of enhancing security of supply and competition in the national wholesale market.

Turkey's liberalization program was initiated in 2001 with the Natural Gas Market Law (Law 4646). While the initial reforms were mainly carried out for the fulfillment of IMF obligations, with the rapidly increasing demand and security concerns, energy supply security was prioritized. In this sense, diversification of gas importers and benefiting from competition among the upstream suppliers was sought (Hacisalihoglu, 2008). As Turkey is not endowed with hydrocarbon resources and is a net-importer, liberalizing its underdeveloped and idle market structure marked by vertical integration, public ownership and inefficiencies, and deregulating the competitive segments became the new policy paradigm (Shamrai, 2006).

In line with the acquis communitaire, in Turkey an independent NRA was instituted (EMRA, 2001) which regulated tariffs for the natural monopoly segments, free entry into the market was promoted, and TPA and unbundling were controlled by the NRA to promote liquidity (Akcollu, 2006). As a part of the liberalization program the legal unbundling of the incumbent, BOTAȘ, is awaited. It is argued that entry at supply level and gas-to-gas competition would be boosted after the unbundling as connectedness and effectiveness of the network service as well as fair and transparent access to the network can be maximized. The increasing convergence of the Turkish gas regulatory framework with the EU and the development of common infrastructure projects such as the Southern Gas Corridor, has led to the problems of BOTAS's incumbency becoming more imminent (Bozhenko, 2011). The existing legislative framework also challenges BOTAŞ's incumbency. In 2007, the monopoly position of BOTAŞ in the import and wholesale markets was partially diluted as third party suppliers gained access to the network to ship their gas. Further import contracts are supposed to be released to third parties through contract/gas/volume release programs until BOTAŞ's share in the relevant market drops to $20 \%$.

The legal unbundling of the BOTAŞ transmission, supply and storage operations was planned to be undertaken in 2009 with supply and storage entities being privatized until2011. ${ }^{9}$ In the interests of Turkey's national security, the natural gas transportation system remains the property of the state-owned monopoly BOTAŞ. BP, 2014a,b, the unbundling had still not been undertaken and BOTAS is still the dominant incumbent, albeit with minor developments in terms of dilution of its dominance. In compliance with the Law, only the accounting unbundling of companies has been fulfilled. Nevertheless, in the new draft of natural gas market law awaiting ratification in the Turkish national Assembly, ownership unbundling of BOTAŞ is envisaged, and in 2015, the company will be split into the three legal entities of transportation, LNG and storage operations, import/wholesaler (Rzayeva, 2014).

De jure, Law 4646, allows private companies to invest in and construct their own transport pipelines (Natural Gas Market Law, 2001). This provision brings to an end the statutory monopoly of BOTAS over transmission. Until recently, however, no party has applied to the NRA requesting a transmission license and the de facto monopoly of BOTAS continues. The rationale behind the reluctance to enter the transmission business is that it is not cost-

\footnotetext{
${ }^{9}$ Natural Gas Market Law: 4646, Accepted on 18.04.2001.
}

effective for the investing company to build a pipeline and transport gas with the existing TPA regime in place.

Enjoying a de facto monopoly position over transmission, BOTAS has expanded its transport system to cover the whole of Turkey. The current total length of the system is nearly $12.500 \mathrm{~km}$. BOTAS is planning to invest in loop-lines and new high pressure compressor stations to enable all contracted volumes to be carried, especially from its Eastern suppliers. Natural gas is taken off the system at around 270 pressure through reduction and metering stations, which are directly connected to the system (BOTAS, 2014). Natural gas enters the main BOTAŞ transport system at the following points;

1. From Azerbaijan through Ardahan

2. From Iran through Ağrı

3. From Russia through Malkoçlar (Balkan) and through Samsun (Blue Stream)

4. From Algeria, Nigeria and spot LNG suppliers through LNG terminals at Marmara Ereglisi and Egegaz Aliaga, İzmir

5. From the TPAO underground store at Marmara Degirmenköy

6. From two production sites in Turkey (TPAO Akçakoca Çayagzı Production and TEMI Edirne Production).

The basic principles applicable to the network access and detailed obligations of transportation licensee are provided in the Transmission Network Operation Regulation, issued by the EMRA on October 26, 2002. BOTAŞ started preparing the 'Third Party Access to the Transport System' in 2003 under the name BOTAŞ Transmission Network Operation as approved by the Council of Ministers. At the same time BOTAS started preparing the 'Transportation and Dispatch Control Tariff to be submitted to the Council of Ministers for approval in line with this provision and the company is bound by those regulations (Competition Authority, 2012). Under article 16.1 of the Network Code, any disputes arising between the shipper and the transporter in respect of the issues of capacity reservations, cancellations, allocations, system balancing participation fees, interruption balancing fees, service interruption fees, emergency, tough day and limited-capacity day practices are to be resolved by EMRA (EMRA, 2012).

Regarding the national gas transmission in Turkey, the realization of TANAP will mark the beginning of a new era. As explained above, although TANAP is accepted as an international gas transit project it is not a cross-border pipeline. The project is designed also to feed the Turkish domestic market. Gas purchase and sales agreement between Turkey and Azerbaijan have been signed in 2011 for $6 \mathrm{bcm}$. Accordingly, Turkey would receive up to $6 \mathrm{bcm}$ of Azerbaijani gas for its own consumption through the BOTAŞ network. For BOTAŞ, it would be cheaper to transport this gas from the Shah Deniz II field starting from 2018, via its own infrastructure rather than TANAP. The cost of transportation for $1000 \mathrm{~cm}$ of gas from Turkish Eastern border to Eskişehir is calculated to be 90\$, considerably higher than the current BOTAȘ transmission tariff, 13\$ (Hurriyet, 2014). Thus, this transmission system will mean that BOTAŞ will be in competition with itself.

The Turkish gas regulatory framework applies a TPA to BOTAŞ's transmission system, under the control of EMRA; however, TANAP has not been and will not be subject to the TPA as the project is completely exempt from the national market regulation. Therefore, without an exemption procedure similar to TAP; TANAP is fully exempted from gas and transportation tariffs, capacity expansion, TPA and any other ex post regulation governed by the IGA and HGA. Despite the fact that the legislative sources of TPA exemption differ, TAP and TANAP projects are granted exemptions in order to promote investment and competition both within the EU and Turkey. As only market tests and existing competitors' willingness for 
expansion capacity can expose the project's true impact on the competitiveness of the domestic market, TANAP should be tested in these terms as well. Furthermore, BOTAŞ's already strong dominance cannot be diluted if TANAP is fully exempted with no limits for the dominant company as given in the TAP decision. The main point is that TANAP is the only non-cross-border pipeline, which is not subject to domestic law although it has the ability to stimulate competition as well as supply security within Turkey with the throughput guarantee. Unique among other Eurasian counterparts, only TANAP has the virtue of ending the incumbent's dominance in gas markets as long as the necessary regulatory framework in line with that of the EU is in place. The point is that TANAP is not only important for supply security but also for the de facto ending of BOTAS's monopoly in transmission and thus will bring competition. However, the regulators not being bound by normative and legislative principles similar to the EU have not yet exploited TANAP's unique position to increase efficiency in the domestic gas market.

\section{Conclusion}

Long distance international pipelines represent peculiarities of international gas trade in Eurasia. They interconnect producer countries with the importers and constitute an extensive transit network, accessed by various parties. Among these natural gas pipelines, TANAP project is sui generis compared to its counterparts because although it is an international gas transit project, it is not a cross-border pipeline. Its physical characteristics make it more a national pipeline rather than an international one, promising competition for the domestic market. TANAP is part of Southern Gas Corridor and its assessment cannot be considered to be in isolation from its interrelated parts. Its unique position derives from it being an international transit project and a domestic pipeline serving both the supply security of the EU and Turkey. Moreover, like the TAP project, it has been granted exemption from all relative regulation although the legislative source of their exemption regime differs. In order to guarantee investment and diversify source countries, TAP has been granted a partial exemption from the European Commission in 2013. TANAP, on the other hand, is fully exempted from national regulation, governed solely by the IGA and HGA.

Since BOTAS is the dominant incumbent and its unbundling is foreseen by the Natural Gas Market Law, an assessment taking account of competition and supply security targets is necessary to determine how this new source of gas can be rendered a procompetitive tool for the Turkish gas market. If the TAP exemption decision is taken as a benchmark, the discussion should be opened in relation to the concerns that should be considered in advance. In this way, by the time TANAP becomes operational initial the $6 \mathrm{bcm}$ capacity and later the expansion capacity (with forward and reverse flows) offers advantages to the long-desired wholesale market liquidity in Turkey. TANAP's promise of enhancing supply security should be accompanied by a transparent and fair access/ exemption regime similar to its counterpart in the EU where the essential facilities doctrine and strategic underinvestment argument (Article 102 of TFEU) have been vigorously employed to further the goals of gas market liberalization. TANAP can also act as an initiator to dispense with existing market distortions (structural and behavioral) in Turkish gas wholesale market.

The necessary institutional framework should be established from the outset to provide actual and potential players with certainty before the infrastructural and commercial arrangements become too complex. TANAP has the virtue of being the first and contemporarily the sole case among the non-EU members of the larger Eurasian continent who have failed to dilute the dominance of Russia over supply and transmission due to international and cross-border character of the pipelines analyzed in this article. TANAP and its potential effects for the Turkish gas market should serve as an important example for future projects. The Turkish gas market is already a unique case in Eurasian energy markets; neither as liberal as markets to the West and nor as concentrated as markets to the East and the TANAP consolidates this uniqueness of Turkish market with its sui generis character.

\section{References}

Akola, F.L.Y., 2006. Major Challenges to the Liberalization of Turkish Natural Gas Market. Oxford Institute of Energy Studies.

An EU Energy Security and Solidarity Action Plan, 2014. Available at: http://eur-lex. europa.eu/LexUriServ/LexUriServ.do?uri=COM:2008:0781:FIN: EN:PDF.

Bilgin, Mert, 2011. Energy policy in Turkey: security, markets, supplies and pipelines. Turk. Stud. 399-417.

BOTAS, 2014. Natural Gas Transmission Lines. Available at: http://www.botas.gov.tr/ index.asp (accessed 16.01.15.).

Bozhenko, E.V., 2011. Perspektivi Vzaimodeystvija Rinkov Prirodnogo Gaza v Turtsii i Stran EC i Interesi Rossii (Perspective of gas market interaction in Turkey and EU and Interest of Russia) (Unpublished PhD thesis). MGIMO, Moscow.

BP, 2013. Statistical Review of World Energy. Available at: http://www.bp.com/ content/dam/bp/pdf/statistical-review/statistical_review_of_world_energy_ 2013.pdf (accessed 16.01.15.).

BP, 2014a. South Caucasus Pipeline. Available at: http://www.bp.com/en_az/ caspian/operationsprojects/pipelines/SCP.html (accessed 16.01.15.).

BP, 2014b. Agreement between Georgia and Azerbaijan Republic. Available at: http://www.bp.com/content/dam/bp-country/en_az/pdf/legalagreements/ SHA_eng_intergov_Azerbaijan_Georgia_Intergovernmental_Agreement.pdf (accessed 16.01.15.).

Cameron, Peter, 2007. Competition in Energy Markets: Law and Regulation in the European Union, second ed. Oxford UP, Oxford.

A Competition Authority, 2012. Natural Gas Market Sector Report. Available at: http://www.rekabet.gov.tr/File/?path=ROOT\%2FDocuments\%2FSekt\%25c3\% 25b6r\%2BRaporu\%2Fsektorrapor8.pdf (accessed 16.01.15.).

EMRA, 2012. Natural Gas Market Report 2012. Available at: http://www.epdk.gov.tr/ documents/dogalgaz/rapor_yayin/Ddp_yayin_rapor_2012.pdf (accessed 16.01.15.).

European Commission, 2014. Communication from the Commission to the European Parliament and the Council, European Energy Security Strategy. COM(2014) 330 final, Brussels.

Haase, Nadine, 2008. European Gas Market Liberalization: Are Regulatory Regimes Moving towards Convergence? Oxford Institute of Energy Studies, pp. 47-55.

Hacisalihoglu, Bilge, 2008. Turkey's natural Gas policy. Energy Policy 36, $1867-1872$.

Hürriyet, 2014. BOTAS Sistemine 13, TANAP'ta 90 Dolar. Available at: http://www. hurriyet.com.tr/ekonomi/27210984.asp.

Koranyi, David, 2014. European natural gas security in an era of import dependence. RUSI J. 159 (2), 66-72.

Merlino, Pietro, Faella, Gianluca, 2013. Strategic underinvestment as an abuse of dominanceunder EU competition rules. World Compet. 36 (4), 513-539.

Mitrova, Tatiana, 2009. Energy security and evolution of the gas markets. Energy Environ. J. 1-8.

Nanay, Julia, Stegen, Karen Smith, 2012. Russia and the caspian region: challenges for transatlantic energy security? J. Transatl. Stud. 10 (4), 343-357.

Natural Gas Market Law, 4646, 2001, available at: http://www.mevzuat.gov.tr/ MevzuatMetin/1.5.4646.pdf (accessed 16.01.15.).

Petroturk, 2014. Tanap Anlaşmasondaki Değişiklikler Onaylandı. Available at: http://www.petroturk.com/HaberGoster.aspx?id=11144\&haber=TANAPAnlasmasindaki-degisiklikler-onaylandi (accessed 16.01.15.).

Rzayeva, Gulmira, 2014. Natural Gas in the Turkish Domestic Energy Market: Policies and Challenges. The Oxford Institute for Energy Studies, Oxford. OIES paper NG 82,

Shamrai, P.S., 2006. Osnavnie napravlenija energeticheskoy strategii Turtsii i ee vlijanie na energeticheskuyu politiku Rossii (Fundamental direction of Turkish energy policy and its influence over policy of Russia). Unpublished PhD. thesis (Moscow).

Talus, Kim, 2013. EU Energy Law and Policy: a Critical Account. Oxford UP, Oxford.

Viscusi, W. Kip, et al., 2005. Economics of Regulation and Antitrust, fourth ed. The MIT Press, Massachusetts. 